\title{
Isolation, Identification, Characterization and Enzymatic Profile of the New Strain of Pantoea agglomerans
}

\author{
Leonila M.L. Acioly ${ }^{1}$, Vilar J. Carlos ${ }^{3}$, Aline Barbosa da Silveira ${ }^{2}$, Fabíola C. Gomes de \\ Almeida ${ }^{4}$, Thayse Alves de Lima e Silva ${ }^{4}$ and Galba Maria de Campos-Takaki ${ }^{4 *}$ \\ ${ }^{1}$ Doutorado em Ciências Biológicas, Universidade Federal de Pernambuco, 50670-901, \\ Recife, PE, Brasil \\ ${ }^{2}$ Autarchy of Higher Education of Garanhuns (AESGA), 55295-380 Garanhuns, \\ Pernambuco, Brazil \\ ${ }^{3}$ Faculty of Guararapes, 54400-160 Jaboatão, PE, Brazil \\ ${ }^{4}$ Núcleo de Pesquisa em Ciências Ambientais e Biotecnologia, Universidade Católica de \\ Pernambuco, 50050-590 Recife, PE, Brasil \\ *Corresponding author
}

\section{A B S T R A C T}

\begin{tabular}{|l|}
\hline Ke y w o r d s \\
$\begin{array}{l}\text { Pantoea, Industrial } \\
\text { effluent, Biochemical } \\
\text { characteristics, Fatty } \\
\text { acids. }\end{array}$ \\
\hline Article Info \\
\hline $\begin{array}{l}\text { Accepted: } \\
\text { 28 September } 2017 \\
\text { Available Online: } \\
\text { 10 November } 2017\end{array}$
\end{tabular}

Enterobacteriaceae of the genus Pantoea are characterized as Gram-negative and have been isolated from a wide variety of environments including soil, water, dust, dairy products, meat, fish, insects, humans and animals. Most of the time they are found associated with a wide variety of plants. The objective of this work was to identify and characterize biochemical, morphological and enzymatic activity, as well as the influence of abiotic factors in a Pantoea isolated from industrial laundry effluent in Pernambuco. The results showed that the bacterium presents characteristics similar to those presented by the species of Pantoea agglomerans; however, the biochemical and morphological tests were not enough to accurately identify the species. However, the isolated species showed production of enzymes such as cellulase, protease and polyphenoloxidase, demonstrating enzymatic biotechnological potential. In addition to tolerance to high concentrations of salinity, they present as mesophyll, cerscendo in optimal temperature of $30^{\circ} \mathrm{C}$ and good growth in the $\mathrm{pH} 7.0$ and 8.0.

\section{Introduction}

The genus Pantoea belongs within the family Enterobacteriaceae and was proposed by Gavini et al., (1983) for two groups of strains that were, at that time, assigned to the Erwinia herbicola-Enterobacter agglomerans complex (Verdonkck, 1987). This complex covered many phena and genomic groups
(Brenner at al., 1984), some of which were later designated as new genera (Grimont; Grimont, 2005).

The enterobacterial genus Pantoea currently comprises nineteen species of Gram-negative, yellow or beige pigmented, motile rods 
(Kageyama at al., 1992). Grimont and Grimont (2005) stated that the genus Pantoea can be envisioned to include DNA groups I, II, IV and V as determined by Brenner et al., (1984). It was further observed that the species $P$. citrea, $P$. punctata and P. terrea, isolated in Japan and described by Kageyama et al., (1992) differed from the "core", Pantoea species in several biochemical or nutritional characteristics. Grimont and Grimont determined the phylogenetic position of all currently recognized Pantoea species and DNA groups of Brenner et al., (1984) using $16 \mathrm{~S}$ rRNA- and rpoB-sequence comparisons and found that the "Japanese" species constituted a cluster that joined the Pantoea cluster at a lower level. They concluded that more taxonomic work was needed to justify the assignment of these species to the genus Pantoea (Braddy et al., 2008; Braddy et al., 2009; Braddy et al., 2010 $a, b)$.

Identification of plant-pathogenic Pantoea species is difficult, due to the high degree of phenotypic similarity between species of this genus and related Enterobacteriaceae. Pantoea species are typically characterised based on colony morphology, physiological and biochemical tests, and in some cases, fatty acid analysis or quinone composition. This approach has proven to be unreliable though, as identification based solely on phenotypic characteristics has led to the misidentification of many strains belonging to the now obsolete "Erwinia herbicolaEnterobacter agglomerans" complex (Brady et al., 2007).

The genus presents short bacilli, Gram negative, $0.5-1.0 \mu \mathrm{m}$ in diameter and 1.0-3.0 $\mu \mathrm{m}$ in length, are mobile by peritrichal flagella and many samples produce yellow or beige pigment. They are facultative anaerobes, negative indole, Voges-Proskauer and Simmons citrate positive, the reaction of methyl red is variable. They do not decarboxylate lysine, do not produce $\mathrm{H}_{2} \mathrm{~S}$ and do not hydrolyze urea (Holt et al., 1994; Camatti-Sartori et al., 2008; Cabral, 2010; Roper, 2011; Nadaeasah; Stavrinides, 2014).

Members of this genus Pantoea have been isolated from a wide range of environments including soil, water, dust, dairy products, meat, fish, insects, humans and animals (Suen et al., 2010; Prakashi et al., 2015; Büyükcam et al., 2017). However, Pantoea agglomerans, is not an obligate infectious agent in humans. However, it could be a cause of opportunistic human infections, mostly by wound infection with plant material, or as a hospital-acquired infection, mostly in immunocompromised individuals (Dutkiewicz et al., 2016).

Most frequently they are found associated with a broad range of plant hosts, as nonpathogenic endophytes or epiphytes, colonizing the leaves, stems and roots. In this context, some Pantoea strains can be beneficial to the plant host by contributing to growth promotion through processes such as the production of the plant-growth hormone indole-acetic acid (IAA), phosphate solubilization or nitrogen fixation (Mishra et al., 2011; De Maayer et al., 2012). Some Pantoea strains also provide effective protection to plants against various bacterioses as well as fungal diseases and postharvest fruit rots (Smits et al.,2011).

The objective of this study was to isolate from laundry efluent, identification, characterization and enzymatic profile.

\section{Materials and Methods}

\section{Sample and Isolation}

Bacteria were isolated from industrial laundry effluents. A quantity of $1 \mathrm{ml}$ of water from each of the samples collected was dissolved in 
$9 \mathrm{ml}$ of sterile distilled water and serial dilutions were made. Each dilution was seeded in Luria Bertani (LB) agar by standard plate spreading method. The plates were incubated at $37^{\circ} \mathrm{C}$ for 3 days and the colonies were transferred from the plates to inclined tubes with the same medium. After plaque growth, bacterial colonies were collected according to their morphological characteristics and purified by striations repeated on plates containing nutrient agar and identified with Gram staining. For the characterization, the biochemical and physiological tests were used for the morphology of the colonies. The strain was routinely cultured in LB medium and maintained at $5{ }^{\circ} \mathrm{C}$.

\section{Biochemical Tests and Morphology}

Bacteria were identified according to macroscopic appearance (colony appearance in solid medium, shape, texture and pigmentation), Gram staining, mobility tests, oxidase, catalase and indole. These tests were done according to Cappuccino and Sherman (1992) and (Grimont;Grimont, 2005). The biochemical Tests were done with various sources of carbon, as monosaccharides (Dglucose, D-fructose, D-xylose, D-mannose, D-mannitol and D-gluconase), disaccharides (lactose, maltose, trehalose and sucrose) (Brown;Dilworth, 1975). Proteins (gelatin) were evaluated according to the standard method (Cappucino; Sherman, 1992).

\section{Abiotic Stress Factors}

\section{pH Effect}

The $\mathrm{pH}$ effect was tested on Nutrient Broth with values of $4,5,6,7,8$, and 10 . The medium was inoculated with $100 \mu \mathrm{l}$ of the culture, grown to a 0.5 standard on the MacFarland scale, And inoculated at $30^{\circ} \mathrm{C} /$ $48 \mathrm{~h}$. The experiment was carried out in triplicate. Growth was evaluated using the spectrophotometer at $600 \mathrm{~nm}$ (Son et al., 2006; Silini-Chérif et al., 2012).

\section{Temperature Effect}

The effect of different temperatures $(4,30$, 37,41 and $44^{\circ} \mathrm{C}$ ) on bacterial growth was evaluated. The nutrient broth medium was inoculated with $100 \mu 1$ of the culture, grown to a 0.5 standard on the MacFarland scale. The growth time was $48 \mathrm{~h}$ and the experiment was performed in triplicate. Growth was evaluated using the spectrophotometer at $600 \mathrm{~nm}$ (SiliniChérif et al., 2012).

\section{Saline Concentration Effect}

The tolerance of the microorganism to an increasing concentration of $\mathrm{NaCl}(0-100 \mathrm{mM})$ in Nutrient Broth medium was evaluated. In the medium, $100 \mu \mathrm{l}$ of the culture was added, grown to a pad of 0.5 on the MacFarland scale. The growth was evaluated at the end of $48 \mathrm{~h} / 30^{\circ} \mathrm{C}$, using the spectrophotometer at $600 \mathrm{~nm}$. The method was performed in triplicate (Son et al., 2006; Silini-Chérif et al., 2012).

\section{Detection of Enzymatic Activity}

\section{Detection of amylase}

For the detection of aminolytic activity, the methodology described by Hankin and Anagnostakis (1979) was used, using the Nutrient Agar medium containing 0.2\% starch, later distributed in Petri dishes. After solidification of the medium, a hole was made in the center of the plate, where a previously prepared bacterial suspension of $100 \mu \mathrm{L}$ was inoculated with $\left(10^{7} / \mathrm{CFU}\right)$. The plates were incubated at $35^{\circ} \mathrm{C}$ for 96 hours with daily monitoring. The enzyme production was evidenced after washing the plates with a lugol solution, by forming an opaque halo 
around the colony. All assays were performed in triplicate.

\section{Detection of Urease}

For the detection of urease activity, the method of Hankin and Anagnostakis (1979) was used, using the nutrient agar medium (lower layer), with addition of 5\% urea. The top layer was made with phosphate buffer agar plus 5\% urea solution and 5\% bromothymol blue solution. After solidification of the culture medium, a hole was made in the center of the Petri dish, with a diameter of $0.8 \mathrm{~cm}$, in which $100 \mu \mathrm{L}$ of the previously prepared bacterial suspension was inoculated. Plates were incubated at 28 and 37 ${ }^{\circ} \mathrm{C}$ for 96 hours with daily monitoring. After the period of microbial growth, a light yellow halo around the colony indicated the presence of urease. All assays were performed in triplicate.

\section{Detection of Tanase}

For the detection of tannic acid activity, a medium having the following composition was used: $3 \mathrm{~g}$ of sodium nitrate, $1 \mathrm{~g}$ of dibasic potassium phosphate, $0.5 \mathrm{~g}$ of magnesium sulfate, $0.5 \mathrm{~g}$ of Potassium chloride, $20 \mathrm{~g}$ of agar, $4 \mathrm{~g}$ of tannic acid, $0.04 \mathrm{~g}$ of bromophenol blue and $1000 \mathrm{ml}$ of distilled water (Sharma et al., 2000). Another medium with the same composition was also prepared, however, by removing the bromophenol blue and increasing the tannic acid concentration to $20 \mathrm{~g}$. After sterilization in autoclave $\left(121^{\circ}\right.$ C, $1 \mathrm{~atm}, 20 \mathrm{~min}$.), These media were poured into Petri dishes, solidified and inoculated using triplicates and control (uninoculated).

After solidification of the culture medium, a hole was made in the center of the $0.8 \mathrm{~cm}$ diameter Petri dish, where $100 \mu \mathrm{L}$ of the bacterial suspension $\left(10^{7} / \mathrm{CFU}\right)$ was inoculated. The plates were incubated at 35
${ }^{\circ} \mathrm{C}$ for 96 hours, with daily monitoring (dark). The degrading activity was evaluated by the appearance of clear zones around the bacterial growth (Hankin; Anagnostakis, 1975).

\section{Detection of Polyphenoloxidase}

The colonies were aseptically removed and transferred to the center of the Petri dish containing modified nutrient agar medium $(5 \mathrm{~g}$ meat extract, $10 \mathrm{~g}$ peptone, $5 \mathrm{~g}$ sodium chloride, $750 \mathrm{ml}$ distilled water, $\mathrm{pH} 6.0$, Tannic acid $5 \mathrm{~g}$ to $125 \mathrm{ml}$ water and gallic acid $5 \mathrm{~g}$ to $125 \mathrm{ml}$ distilled water) and incubated for $24 \mathrm{~h} / 35^{\circ} \mathrm{C}$. The enzymatic activity was observed by the brown halo formation around the colony on the rest of the plaque (Harkin; Obst, 1973).

\section{Detection of Lipase}

For the detection of lipolytic activity a medium was used with the following composition: $10 \mathrm{~g}$ peptone, $5 \mathrm{~g}$ sodium chloride, $0.1 \mathrm{~g}$ calcium chloride bihydrate, 20 g agar, $20 \mathrm{ml}$ tween 20 And tween 80 and $1000 \mathrm{~mL}$ of distilled water. The tween was autoclaved separately in flowing steam and added to the medium before dispensing into Petri dishes. After sterilization in autoclave $\left(121{ }^{\circ} \mathrm{C}\right.$, $1 \mathrm{~atm}, 20 \mathrm{~min}$.), These media were poured into Petri dishes, solidified and inoculated using triplicates and control (without tween). Methodology described by Hankin and Anagnostakis (1979).

\section{Results and Discussion}

\section{Isolation and Characterization of Bacteria}

The isolated bacteria were cultured in nutrient agar (AN) for $24 \mathrm{~h}$ at $30{ }^{\circ} \mathrm{C}$. The colonies obtained had the following macroscopic characteristics: circular, smooth colonies, regular and flat borders, $1 \mathrm{~mm}$ in diameter and yellow pigment. Microscopic 
examination revealed to be a Gram-negative bacillus with rounded ends. They were presented alone or in pairs. It is mobile, catalase positive, facultative anaerobic, nonfermenting glucose (Table 1).

The results obtained corroborate those found by Silini-Cherif and collaborators (2012) in the identification of a strain of Pantoea agglomerans IMA2 isolated from wheat rhizosphere. Fujikawa and Akimoto (2011) also show similar results for Pantoea agglomerans. The biochemical characteristics presented by the bacterium isolated from industrial laundry residue are also similar to the strains of $P$. ananatis and $P$. stewartii (Delétoile et al., 2009).

Gavini et al., (1989) and Mergaert (1993) describe the genus Pantoea as bacilli of 0.5$1.3 \times 1.0-3.0 \mu \mathrm{m}$. Non-encapsulated and nonspore forming. Most of the strains are mobile by means of perimeter, Gram-negative flagella and colonies when grown on nutrient agar are smooth, translucent with covex or heterogeneous margins in whole consistency and adhering to agar.

The colonies are yellow, beige or nonpigmented, facultative anaerobes. The optimum temperature of growth is around 28 and $30^{\circ} \mathrm{C}$. Oxidase negative.

Glucose dehydrogenase and gluconate dehydrogenase are produced and are active without an added cofactor. Lysine and ornithine are not decarboxylated, urease negative, does not degrade pectin, $\mathrm{H}_{2} \mathrm{~S}$ is not produced from thiosulfate. Most of the strains are Voges-Proskauer-positive and indolnegative. The acid is produced from the fermentation of $\mathrm{L}$-arabinose, D -ribose, D xylose, D-galactose, D-fructose, Lramnose, D-mannitol, N-acetylglucosamine, maltose and trehalose. The sources of carbon used at $28{ }^{\circ} \mathrm{C}$ (Biotype-100) are D-glucoside, D- fructose, D-galactose, trehalose, D-mannose, cellobiose, 1-O-methyl $\beta$-D-glucopyranoside, L-arabinose, Glycerol, and $\mathrm{L}$-serine. The sources of unused carbon at $28{ }^{\circ} \mathrm{C}$ (Biotype100) are L-sorbose, palatinose, melezitose, maltitol, turanose, tricarballylate, 4hydroxybenzoate, gentisate, methyl 3hydroxybenzoate, methyl benzoate, 3phenylproprionate, $\mathrm{M}$-cammarate, histamine, caprate, caprylate, glutarate, 5-aminovalerate, ethanolamine, tryptamine, itaconate, 3hydroxybutyrate, propionate and L-tyrosine. Reference strains were isolated from plants, seeds, fruits, soils and water, and from humans (urine, blood, wounds, internal organs) and other animals. Strains of various species are phytopathogenic in a wide range of facilities and agricultural machinery. The $\mathrm{G}$ $+\mathrm{C}$ content of the DNA varies from 52.7-60.6 mol\% (Deletoile et al., 2009; Duron et al., 2016).

\section{Biochemical Characterization}

The results of several biochemical tests were listed in Table 1. The Pantoeasp. Degraded some carbon sources such as D-mannitol, Dmannose, D-glucose, D-gluconase, D-fructose and sucrose. And also the gelatin protein. He presented $\mathrm{H}_{2} \mathrm{~S}$ production and was positive for the Voges-Proskauer test, methyl red and lactose. According to Delétoile et al., (2009) and Mergaert et al., (1993) these are characteristics of the strains of Pantoea agglomerans.

\section{Responses to Abiotic Stress}

Pantoea sp. Demonstrated great growth ability over a broad $\mathrm{pH}$ range, ranging from $\mathrm{pH} 4.0$ to $\mathrm{pH} 8.0$. There was inhibition of growth for alkaline $\mathrm{pHs}$ ( $\mathrm{pH} 9.0$ and 10.0). The bacteria showed optimum growth at $\mathrm{pH}$ 7.0 (Figure 1). The results were similar to those reported by Pantoea agglomerans CPA2 and Pantoea agglomerans IMA2 in works 
presented by Costa et al., (2002), Son et al., the highest development of Pantoea occurs in (2006) and Silini-Chérif et al., (2012), culture medium with $\mathrm{pH}$ values ranging from respectively. Other studies have reported that 6.0 to 7.0 (Costa et al., 2002).

Table.1 Biochemical tests and acid production to bacterialidentification

\begin{tabular}{lclc}
\hline BiochemicalTests & Bacterial strain & $\begin{array}{l}\text { Acid } \\
\text { production }\end{array}$ & Bacterial strain \\
\hline Motility & + & D-glucose & + \\
Yellow Pigment & + & D-fructose & + \\
Catalase & + & D-xylose & - \\
Citrate & - & D-mannose & + \\
Lactose & + & D-mannitol & + \\
Methyl red & + & D-gluconase & + \\
Glucose & - & Lactose & - \\
Indol production & - & Maltose & - \\
Production H2S & + & Trehalose & + \\
Reaction Voges-Proskauer & + & Sucrose & + \\
\hline
\end{tabular}

+: Positive Test; -: Negative Test.

Fig.1 Effect of different pHin nutrient broth medium on the growth of Pantoea sp.at 48 hof incubation

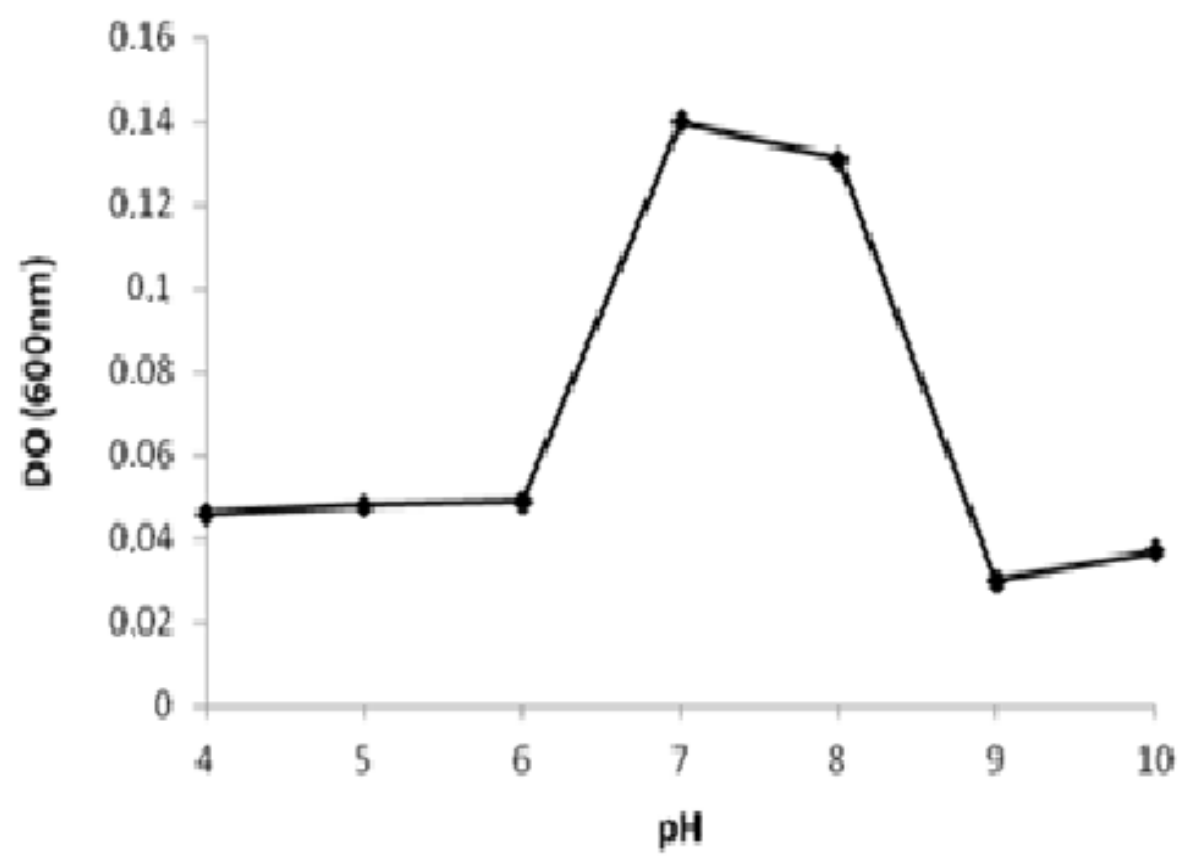


Table.2 Enzyme production by bacterial strain isolated from laundry effluent

\begin{tabular}{l|c}
\hline Enzyme Activity & Bacterial strain \\
\hline Urease & - \\
\hline Protease & - \\
\hline Amylase & - \\
\hline Tanase & + \\
\hline Polyphenoloxidase & + \\
\hline Cellulase & + \\
\hline
\end{tabular}

The turbidity measurement, for growth at different temperatures, showed a significant result at $30^{\circ} \mathrm{C}$, indicating that the tested Pantoea lineage is mesophilic (Figure 2). Similar results were found by Camatti-Sartori et al., (2008) when evaluating the influence of temperature on the growth of Pantoea agglomerans and obtained the best results at temperatures of $30^{\circ} \mathrm{C}$. The microorganism showed good viability of growth at high temperatures of 40 and $44^{\circ} \mathrm{C}$ (Figure 2), which could explain the presence of these organisms in arid regions (Silini-Chérif et al., 2012).
However, Camatti-Sartori et al., (2008) presented discordant results regarding the temperature of $40{ }^{\circ} \mathrm{C}$, because there was a significant decrease in the development of the microorganism. Son et al., (2006) worked with insoluble phosphate solubilization by Pantoea agglomerans and obtained good microorganism growth results in a temperature range between 5 and $45^{\circ} \mathrm{C}$. With best results at $25-35^{\circ} \mathrm{C}$. Temperature is one of the most important factors governing the physiology and growth of microorganisms, as reported by Rahman et al., (2006).

Fig.2 Evaluationof temperatures $\left({ }^{\circ} \mathrm{C}\right)$ of incubation on the growth of Pantoea spin the nutrient broth medium at $48 \mathrm{~h}$

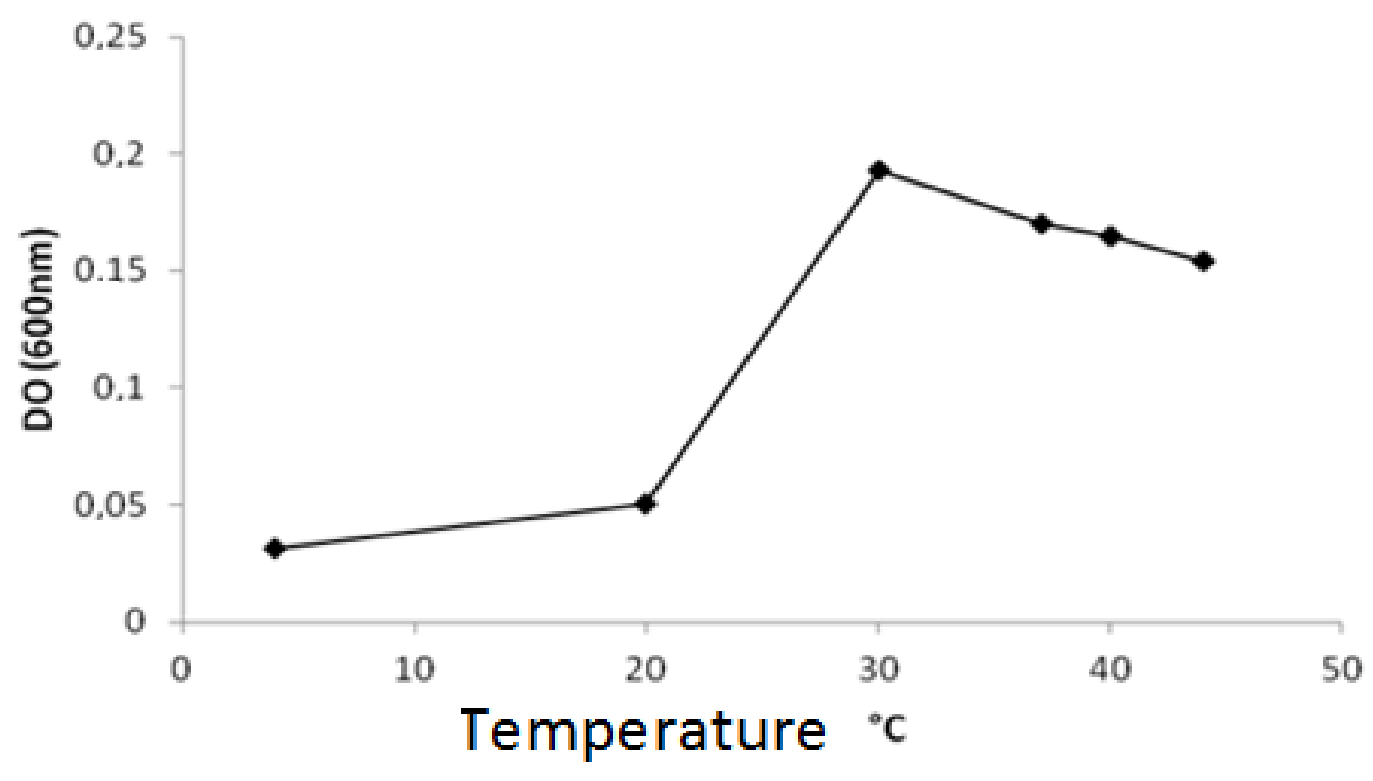


Fig.3 Effect of different concentrations of $\mathrm{NaCl}(\mathrm{mM})$ in nutrient broth medium on the growth of Pantoea sp.at $48 \mathrm{~h}$ of incubation

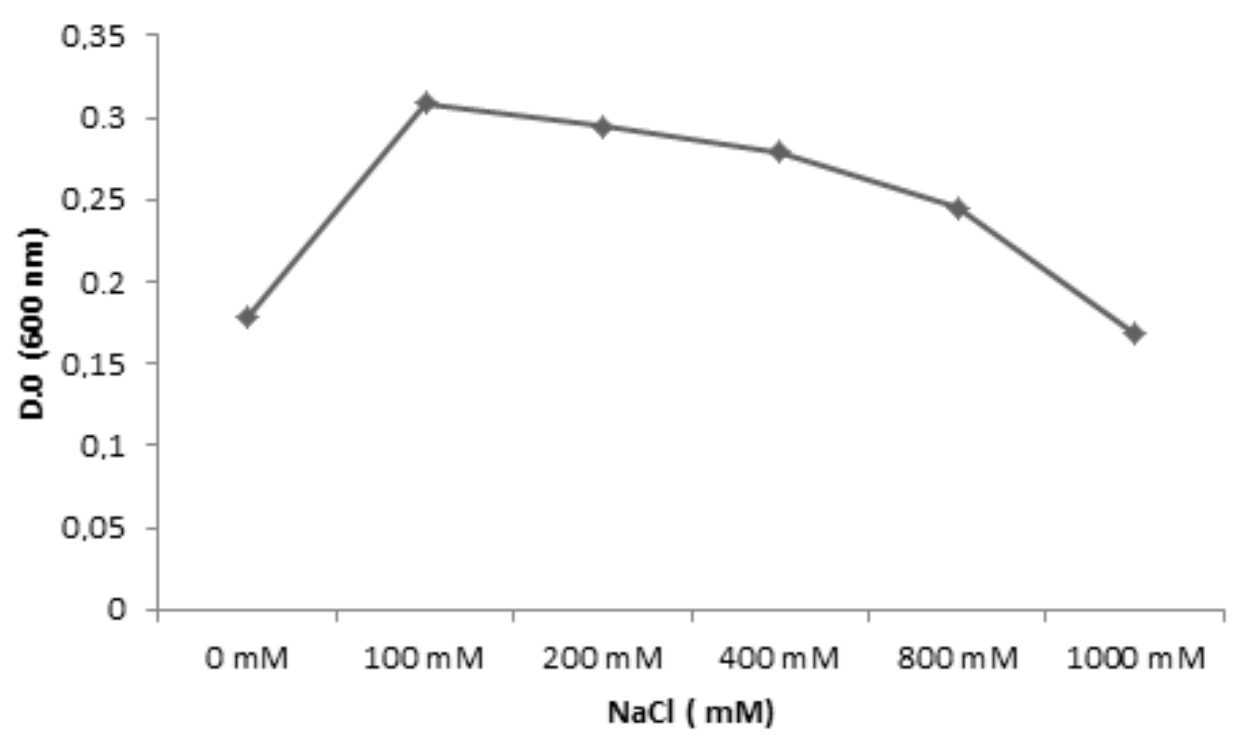

Growth of the nutrient broth strain with variations in salt concentration from 0 to 1000 $\mathrm{mM}$ showed a high tolerance capacity at high salt concentrations. The high point of growth was with $100 \mathrm{mM}$. However, it presented excellent results at concentrations of 400,800 and $1000 \mathrm{mM} \mathrm{NaCl}$ (Figure 3). According to Borneman et al., (1996), soil salinity plays an important role in the microbial selection process. Several studies indicate that bacteria isolated from saline environments are better able to survive inhibition concentrations compared to non-saline isolates (Sharma, 2006). Similar results were found by SiliniChérif et al., (2012) when working with a strain of Pantoea agglomerans.

\section{Enzymatic Profile of Pantoea agglomerans}

Microbial enzymes have an essential role in the processes related to soil quality, since it is through them that the soil microorganisms degrade complex organic molecules in simple and that can be assimilated. In addition to allowing microorganisms to have access to the energy and nutrients present in complex substrates, extracellular enzymes are responsible for the decomposition and mineralization of nutrients in the soil, also making them available to plants and promoting the cycling of nutrients in the soil (Makol; Ndakidemi, 2008). The bacterium of the genus Pantoeasp was submitted to enzyme activity detection tests for amylase, urease, protease, tannase, cellulase and polyphenoloxidase. Pantoeaagglomerans isolated from laundry efluent showed positive results for enzymes tanase, polyphenoloxidase and cellulase (Table 3). Tannase is an enzyme that hydrolyzes esters and side bonds of hydrolysable tannins producing glucose and gallic acid (Banerjje et al., 2001). It is mainly used for the production of gallic acid, instant teas, wine color stabilization, leather treatment process, food detanification, antioxidant production and effluent treatment in the leather industry (Battestin et al., 2004;).

Madhukar et al., (1996) and Souza and Magalhãs (2010 detected the enzymatic activity of amylase and cellulase by Pantoea agglomerans isolated from pea leaves (Lathyrus maritimus L). Cellulases are used in many biotechnological applications. In the 
textile industry, these enzymes are used to give better finishing to the fabrics, making them smoother, smoother and with better trim. Cellulases are also used in the beverage industry for the production of fruit juices and in winemaking processes. Also, they play an important role in animal nutrition, detergent manufacturing, and the paper pulp industry, making the paper whiter and smoother. However, interest in these enzymes has increased greatly due to their use in the ethanol production process (Castro; Pereira, 2010).

Phenol oxidase-catalyzed reactions are related to changes in cell wall properties (increased impermeability and hydrostatic resistance), intracellular interactions and removal / detoxification of certain secondary metabolites (Mayer; Harel, 1979; Mardaneh; Dallal, 2013; Dushyanthie to al., 2014).

The biochemical and morphological tests showed that the microorganism isolated is of the Pantoea genus and presents characteristics similar to those presented by Pantoea agglomerans. The Pantoea strain studied showed tolerance to high salt concentrations, optimum growth in mesophilic temeprature codons, 30, $37^{\circ} \mathrm{C}$, and alkaline $\mathrm{pH} 7$ and 8 indicating an enzymatic biotechnological potential for cellulase, tannase and polyphenoloxidase.

\section{Acknowledgments}

The authors wish to thank the Brazilian Research Council (CNPq), Brazil, the Coordination for Improvement of Higher Level Education (CAPES), Brazil and the Foundation for Support of Science and Technology of the State of Pernambuco FACEPE, Brazil. Special thanks are given to Catholic University of Pernambuco for making facilities and infrastructure available for the conduct of this research.

\section{References}

Banerjje, D., Mondal, K.C., Pati, B.R. 2001.Production and characterization of extracellular and intracellular tannase from newly isolated Aspergillus aculeatus DBF9. J. Basic Microbiol., 41, 313-318.

Battestin, V., Matsuda, L. K., Macedo, G. A. 2004. Fontes e Aplicações de Taninos e Tanases em alimentos. Alimentos e Nutrição Araraquara, 15, 63-72.

Brady, C. L., Venter, S. N., Cleenwerk, I., Vandemeulebroecke, K., De Vos, P.; Coutinho, T. A. 2010.Transfer of Pantoea citrea, Pantoea punctata and Pantoeaterrea to the genus Tatumella emend. As Tatumella citrea comb.nov., Tatumellapunctata comb.nov. and Tatumella terrea comb. nov. and description of Tatumella morbirosei sp. nov. Int. J. Syst. Evol. Microbiol, 60, 484-494 b.

Brady, C. L.; Cleenwerck, I.; Venter, S. N.; Vancanneyt, M.; Swings, J.; Coutinho, T. A. 2008. Phylogeny and identification of Pantoeaspecies associated with plants, humans and the natural environmentbased on multilocus sequence analysis (MLSA). Syst. Appl. Microbiol. 31, 447-460.

Brady, C. L.; Venter, S. N.; Cleenwerck, I.; Engelbeen, K.; Vancanneyt, M.,;Swings, J.; Coutinho, T. A. 2009. Pantoea vagans sp. nov., Pantoea eucalypti sp. nov., Pantoea deleyi sp. nov. andPantoea anthophila sp. nov. Int J Syst Evol Microbiol 59, 2339-2345.

Brady, C.,Venter, S.; Cleenwerck, I.; Vancanneyt, M.; Swings, J.; Coutinho, T. 2007. A FAFLP system for the improved identification of plantpathoganic and plant-associated species of the genus Pantoea, Syst. Appl. Microbiol., 30, 413-417.

Brady, C.L.; Cleenwerck, I.; Venter,S.V.; 
Engelbeen,K.; De Vos, P.; Coutinho, T.A. 2010.Emended description of the genus Pantoea, description of four species from human clinical samples, Pantoea septica sp. nov., Pantoea eucrina sp. nov., Pantoeabrenneri sp. nov. andPantoea conspicua sp. nov., and transfer of Pectobacterium cypripedii (Hori 1911) Brenner et al., 1973 emend. Hauben et al., 1998 to the genus as Pantoea cypripedii comb. Nov. Inter. J. Syst.Evol.Microbiol., 60, 2430-2440a.

Brenner, D.J., et al., 1984. Attempts to classify Herbicola group-Enterobacter agglomerans strains by deoxyribonucleic acid hybridization and phenotypic tests, International Journal of Systematic Bacteriology, Ames, 34, $45-55$.

Brown, C.M, Dilworth. 1975. Ammonia assimilation by Rhizobium cultures and bacterioids. J. Gen. Microbiol., 86 3948 .

Büyükcama, A.;Tuncer,Ö.; Gür, D.; Sancak, B.; Ceyhana, M. ; Cengiz, A.B.; Kara, A. 2017.Clinical and microbiological characteristics of Pantoea agglomeransinfection in children.J. Infect Public Health, 783, 1-6.

Cabral,J.P.S. 2010. Water Microbiology. Bacterial Pathogens and Water.Int $\mathbf{J}$ Environ Res Public Health. 7(10): 3657-3703.

Camatti-sartori, V.,Valdebenito-Sanhueza, R.M.,Ribeiro, R.T.S. 2008. Desenvolvimento de Pantoea agglomerans em diversas temperaturas, $\mathrm{pH}$ e concentrações de carboxi-metilcelulose e o seu impacto no controle de Rosellinia necatrix, Summa phytopathologica, , 34, 1, 22-28.

Cappuccino, J.C., Sherman, N, 1992. Microbiology: a laboratory manuel. $3^{\text {rd }}$ Edn, Benjamin/cummings Pub. Co., New York, USA, pp: 125-179.
Castro, A. M., Pereira JR, N. 2010. Produção, propriedades e aplicação de celulases na

Costa, E. et al., 2002. Water activity, temperature and $\mathrm{pH}$ effects on growth of the biocontrol agent Pantoea agglomerans CPA-2. Canadian Journal of Microbiology, 48, 1082-1088.

De Maayer, P., Chan, W.Y., Blom, J., Venter, S.N., Duffy, B., Smits, T.H.M., Coutinho, T.A. The large universal Pantoea plasmid LPP-1 plays amajor role in biological and ecological diversification. BMC Genomics, 625,1471-2164.

Delétoile, A. et al.,2009. Phylogeny and Identification of Pantoea species and Typing of Pantoea agglomerans strains by multilocus gene sequencing.Journal of Clinical Microbiology, 47,300-310.

Duron, O.; Noël, V. 2016. A wide diversity of Pantoea lineages are engaged in mutualistic symbiosis and cospeciation processes with stinkbugs. Envir.Microbiol. Reports, 8,5, 715-727.

Dutkiewicz, J.; Mackiewicz, B.; Kinga Lemieszek, M.; Golec, M.; Milanowski, J. 2016.Pantoea agglomerans: a mysterious bacterium of evil and good. Part III. Deleterious effects: infections of humans, animals and plants.Ann. Agric. Environ. Med.,23,2, 197-205.

Fujikawa, H., Akimoto, R. 2011. New blue pigment produced by Pantoea agglomerans and its production characteristics at various temperatures. Applied and Environmental Microbiology, 77, 172-178.

Gavini, F. et al.,1983.Taxonomic study of strains belonging or related to the genus Erwinia, herbicola group, and to the species Enterobacter agglomerans. Systematic and Applied Microbiology, 4, 218-235.

Gavini, F., et al.,. 1989. Transfer of Enterobacter agglomerans (Beijerinck 
1888) Ewing and Fife 1972 to Pantoea gen. nov. asPantoea agglomerans comb. nov. and description of Pantoea dispersa sp. nov. Inter. J. Syst. Bacteriol., 39, 3, 337-345,

Grimont, P.A.D.; Grimont, F. Genus: Pantoea, in: D.J.Brenner, N.R. Krieg, J.T. Staley (Eds.), Bergey's Manual of Systematic Bacteriology, vol. 2, The Proteobacteria, Part B, The Gammaproteobacteria, second ed., Springer, New York, 2005, pp. 713720.

Gupta, R; Mohapatra, H; Goswami, V.K.; Chauhan, B. 2003. Microbial $\alpha$ Amylases: Biotechnological Perspective. Process Biochem.,38, 1991616.

Hankin, L.; Anagnostakis, S. L. 1979.The use of solid media for detection of enzymes production by fungi. Mycologia, 67, 597-607.

Harkin, J.M., Obst, J.R. 1973.Syringaldazine an affective reagent for detecting laccase and peroxidase in fungi. Experientia, Basel, 29, 381-387.

hidrólise de resíduos agroindustriais. Química Nova, 33,181-188.

Coelho, R.S.,Amarante Junior, O.P., Melo, I.S., Parma, M.M, Vieira, E.M.Identificação de bactérias degradadoras de fluidos de corte por análise dos ácidos graxos. Revista ACTA Tecnológica, 6, n. 2, jul-dez. 2011.

Holt, J.G. et al., Bergey's Manual of Determinative Bacteriology. 9ed. Baltimore: Williams \& Wilkins, p. 787, 1994..

Kageyama, B. et al., 1992. Pantoea punctata sp. nov., Pantoea citrea sp. nov., and Pantoea terrea sp. nov. isolated from fruit and soil samples, Inter. J. Syst. Bacteriology, 42, 203-210.

Madhukar, B. K., Arya K. B., Lisa D. N., John, A. G. 1996. Pantoea agglomerans is the etiological agent for black spot necrosis on beach peas. Can. J. Microbiol., 42, 1252-1257.

Makol, J. H. J. R., Ndakidemi, P. A. 2008. Selected soil enzymes: examples of their potential roles in the ecosystem. African J. Biotechnol., 3, 181-191.

Mardaneh, J. and Dallal, M.M.S.2013.Isolation, identification and antimicrobial susceptibility of Pantoea (Enterobacter) agglomerans isolated from consumed powdered infant formula milk (PIF) in NICU ward: First report from Iran. Iran J Microbiol., 5, 263-267.

Mergaert, J., Verdonck, L., Kersters, K. 1993.Transfer of Erwinia ananas (synonym, Erwinia uredovora) and Erwinia stewartiito the genus Pantoea emend. asPantoeaananas (Serrano 1928) comb. nov. andPantoea stewartii (Smith 1898) comb. nov., respectively, and description of Pantoea stewartii subsp. indologenes subsp. nov., Inter. J. Syst. Bacteriol., 43, 162-173.

Mishra, A.; Chauhan, P.S.; Chaudry, V.; Tripathi, M.; Nautiyal, C.S. 2011.Rhizosphere competent Pantoea agglomerans enhances maize (Zea mays) and chickpea (Cicer arietinum L.) growth, without altering the rhizosphere functional diversity. Antonie Van Leeuwenhoek, 100, 405- 413.

Murray, P. R.; Rosenthal, K. S.; Pfaller, M. A. Microbiologia Médica, 5th ed., Elsevier editora, Rio de Janeiro, 2006.

Nadarasah,G.; $\quad$ Stavrinides, J. 2014. Quantitative evaluation of the hostcolonizing capabilities of the enteric bacterium Pantoea using plant and insect hosts.Microbiol., 160, 602-615.

Prakash,O.; Nimonkar, Y.; Vaishampayan,A.;Mishra, $\quad$ M.; Kumbhare, S.; Josef, N.; Shouche, Y.S.;. 2015. Pantoea intestinalis sp. nov., isolated from the human gut. Inter. 
J. Syst. Evol. Microbiol., 65, 33523358.

Rahman, M. et al.,2006.Effect of some environmental factors on the growth of Azospirillum species isolated from saline soils of Satkhira district, Bangladesh. Bangladesh J. Microbiol., 23,145-148.

Roper, C.M. 2011.Pantoeastewartii subsp. stewartii: lessons learned from a xylemdwelling pathogen of sweet corn. Molecular Plant Pathol.,12,628-637.

Sharma, S.; Bhat, T. K.; Dawra, R. K. 2000.A spectrophotometric method for assay of tannase using rhodanine. Analytical Biochem., 279, 85-89.

Silini-Chérif, H., Silini, A., Ghoul, M.; Yadav, S. 2012.Isolation and characterization of plant growth promoting traits of rhizobacteria: Pantoea agglomerans Ima2. Pakistan J. Biol. Sci., 15, 267-276.

Smits, T.H.M., Rezzonico, F., Kamber, T., Blom, J., Goesmann, A., Ishimaru, C.A.,Frey, J.E., Stockwell V.O., Duffy,
B. 2011.Metabolic versatility and antibacterial metabolite biosynthesis are distinguishing genomic features of the fire blight antagonist Pantoea vagans C9-1. PLoS One, 6, 22-247.

Son, H.J., Park, G.T., Cha, M.S., Heo, M.S. 2006. Solubilization of insoluble inorganic phosphates by a novel saltand $\mathrm{pH}$-tolerant Pantoea agglomerans $\mathrm{R}-42$ isolated from soybean rhizosphere. Biores. Technol., 97, 204210.

Souza, P.M., Magalhães, P.O. 2010. Application of microbial $\alpha$-amylase in industry - a review, Braz. J. Microbiol., $41,850-861$.

Suen, G. et al.,2010. An insect herbivore microbiome with high plant biomassdegrading capacity. PLoS Genet, 6, 1001-1029.

Verdonck, L. et al.,1987. Genus Erwinia: Numerical analysis of phenotypic features, Inter. J. Syst. Bacteriol., 37 418.

\section{How to cite this article:}

Leonila M.L. Acioly, Vilar J. Carlos, Aline Barbosa da Silveira, Fabíola C. Gomes de Almeida, Thayse Alves de Lima e Silva and Galba Maria de Campos-Takaki. 2017. Isolation, Identification, Characterization and Enzymatic Profile of the New Strain of Pantoea agglomerans. Int.J.Curr.Microbiol.App.Sci. 6(11): 4152-4163.

doi: https://doi.org/10.20546/ijcmas.2017.611.487 